UDC 612.12: 616.092

DOI: $10.21668 /$ health.risk/2021.1.05.eng

Research article

\title{
OMIC MARKERS IDENTIFICATION FOR PREDICTING RISKS OF NEGATIVE EFFECTS IN CHILDREN WITH ELEVATED COPPER AND NICKEL CONTENTS IN BLOOD
}

\author{
N.V. Zaitseva ${ }^{1}$, M.A. Zemlyanova ${ }^{1,2}$, Yu.V. Koldibekova ${ }^{1}$, N.I. Bulatova ${ }^{1}$ \\ ${ }^{1}$ Federal Scientific Center for Medical and Preventive Health Risk Management Technologies, 82 Monastyrskaya Str., \\ Perm, 614045, Russian Federation \\ ${ }^{2}$ Perm State University, 15 Bukireva Str., Perm, 614990, Russian Federation
}

Proteomic profiling is a promising procedure for examining and substantiating molecular mechanisms of body reactions occurrence and development as a response to adverse impacts; it allows detecting and examining these reactions at early stages in their development prior to cellular damage and damage to organs. Studies aimed at increasing efficiency of adverse effects prediction are especially vital for solving tasks related to early detection and prevention of consequences associated with exposure to chemical environmental factors, first of all, ambient air.

Our research goal was to identify omic-markers for predicting risks of negative effects in children with elevated copper and nickel contents in blood.

We performed proteomic blood plasma examination in children and modeled cause-and-effect relations. Children with copper and nickel contents in their blood being 3.5 times higher than physiological standard had approximately 20 protein stains that were authentically different from those detected in children from the reference group. We detected correlations between an increase in relative volume of three protein stains including apolipoprotein A-I, anchor protein of A-kinase 9, vitronectin, and a decrease in relative volume of one protein strain including transthyretin and elevated copper and nickel contents in blood $\left(R^{2}=0.30-0.44 ; p=0.0001-0.008\right)$. All the above-mentioned proteins have predictive significance when it comes down to negative effects related to neuroregulation disorders and endothelial dysfunction. It was proven that there was a risk of predicted negative effects such as greater frequency of nervous and cardiovascular system diseases in case copper and nickel contents in blood were elevated $\left(R^{2}=0.35-0.96 ; p=0.0001-0.013\right)$. The established list of potential target molecules (apolipoprotein A-I, vitronectin, anchor protein of A-kinase 9, and transthyretin) and genes that coded their expression (APOA1, VTN,AKAP9,TTR) was substantiated as omic-markers indicating a possibility that negative effects might occur in the cardiovascular and nervous system.

Key words: copper and nickel in blood, health risk, proteomic profile of blood plasma, nervous system, cardiovascular system, apolipoprotein A-I, anchor protein of A-kinase 9, vitronectin, transthyretin.

There are certain priorities fixed within these priorities, research that concentrates on national and international strategies for scientific research development in fundamental medicine for the period up to $2025^{1}$. Given specific changes in regulatory mechanisms of homeostasis at the molecular level becomes especially important since it allows efficient

(C) Zaitseva N.V., Zemlyanova M.A., Koldibekova Yu.V., Bulatova N.I., 2021

Nina V. Zaitseva - Academician of the Russian Academy of Sciences, Doctor of Medical Sciences, Professor, Scientific Director (e-mail: znv@fcrisk.ru; tel.: +7 (342) 237-25-34; ORCID: https://orcid.org/0000-0003-2356-1145).

Marina A. Zemlyanova - Doctor of Medical Sciences, Chief Researcher acting as the Head of the Department for Biochemical and Cytogenetic Diagnostic Techniques (e-mail: zem@fcrisk.ru; tel.: +7 (342) 236-39-30; ORCID: http://orcid.org/00000002-8013-9613).

Yuliya V. Koldibekova - Candidate of Biological Sciences, Senior researcher acting as the Head of the Laboratory for Metabolism and Pharmacokinetics at the Department for Biochemical and Cytogenetic Diagnostic Techniques (e-mail: koldibekova@fcrisk.ru; tel.: +7 (342) 237-18-15; ORCID: http://orcid.org/0000-0002-3924-4526).

Natal'ya I. Bulatova - Researcher at the Laboratory for Biochemical and Nanosensory Diagnostics, Federal Scientific Center for Medical and Preventive Health Risk Management Technologies (e-mail: 1179815@mail.ru; tel.: +7 (3422) 36-80-18; ORCID: https://orcid.org/0000-0003-3392-9097).

${ }^{1}$ On Approval of the Strategy for medical science development in the Russian Federation for the period up to 2025: The Order by the RF Government dated December 28, 2012 No. 2580-r. Garant.Ru. The information and legal portal. Available at: https://www.garant.ru/products/ipo/prime/doc/70192396/ (20.09.2019) (in Russian). 
predicting and assessing potential negative effects at the earliest stage in their development. This research is accomplished with «Prevention medium» scientific platform.

Extremely high ambient air contamination with chemicals, including highly toxic nickel and copper compounds, results in risks of negative effects produced on the respiratory organs, blood system, immune system, and nervous system ${ }^{2}$.

Given that, it becomes especially vital to identify changes in homeostasis at the molecular level. Studies that focus on peptide pools fully correspond to these requirements since such pools play an exceptional role in bioregulation occurring in live organisms. Proteomic profiling is an efficient tool that allows analyzing peptides, as well as their ultimate and intermediate metabolites in a cell [1-4]. This procedure allows examining and substantiating etiological pathogenetic mechanisms of responses occurring and developing in a body due to exposure to adverse factors at their earliest stages, prior to any symptoms of damage to cells and organs, that is, at the level where transformed proteomic blood plasma profile is examined. To predict expression of these peptides, it is important to determine genes that code them; existing databases (for example, Sviss Prot) provide an opportunity to do it. The outlined issue confirms it is vital to perform studies aimed at identifying molecular omic-markers for early detection and prevention of consequences caused by aerogenic exposure to metals $[5,6]$.

Our research goal was to reveal omicmarkers for predicting risks of negative effects in children with elevated copper and nickel contents in blood.

Data and methods. Our research objects were blood plasma samples taken from 20 children aged 4-6 with elevated copper and nickel contents in blood (the test group) and 10 children with these metals detected in their blood in concentrations that corresponded to minimal or reference values (the reference group).

The present research work was accomplished in full conformity with ethical requirements fixed in the Helsinki Declaration (last edited in 2013) and was approved on by the Ethical Committee of the Rospotrebnadzor's Federal Scientific Center for Medical and Preventive Health Risk Management Technologies. Both groups were comparable as per age and gender and didn't have any differences regarding social and economic factors that might cause health risks. Children's legal representatives gave their voluntary written informed consent on underage children's participation in the research and publication of relevant data on them.

Chemical-analytical blood examination aimed at determining nickel and copper contents in blood was performed in conformity with the valid Methodical Guidelines MUK 4.1.3230-14 «Measuring mass concentrations of chemicals in biological media (blood and urine) with mass spectrometry with inductively coupled plasma» ${ }^{3}$. To do that, we used relevant analytical equipment, namely Agilent 7500cx (the USA) mass spectrometer with inductively coupled argon plasma.

Proteomic blood plasma profile of children from the test and reference groups was performed according to two-dimensional electrophoresis procedure in polyacrylamide gel as per methods recommended for the equipment in use [7-9]. Obtained blood plasma electrophoregrams were visualized via dying with silver and documented with a system for geldocumenting (Bio-Rad, the USA). Obtained proteomic maps were analyzed with PDQuest software (Bio-Rad, the USA). We spotted out significant protein stains in obtained proteinograms and performed subsequent analysis via

${ }^{2} \mathrm{R}$ 2.1.10.1920-04. Assessment of population health risks under exposure to chemicals that pollute the environment: Guide. Moscow, The Federal center for state sanitary and epidemiologic surveillance of the RF Public Healthcare Ministry Publ., 2004, 143 p. (in Russian).

${ }^{3}$ MUK 4.1.3230-14. Measuring mass concentrations of chemicals in biological media (blood and urine) with mass spectrometry with inductively coupled plasma. Approved by the RF Chief Sanitary Inspector A.Yu. Popova on December 19, 2014. KODEKS: an electronic fund for legal and reference documentation. Available at: http://docs.cntd.ru/document/495856222 (22.09.2019) (in Russian). 
liquid chromatography combined with massspectrometry with UltiMate chromatograph 3000 (Germany) ABSciex 4000 QTRAP tandem mass-spectrometer with Nanospray 3 ionization source (Canada). Data obtained via tandem experiments were processed with ProteinPilot software, version 4.5 (AB SCIEX) with identification as per UniProt_sprot fasta database (version issued on November 24,2017 ), and with a sampling made as per HomoSapience taxon. Most data on obtained proteins were taken from UniProt databases. We determined genes that identified proteins corresponded to with HGNC database of human gene name.

Sampling properties were given as simple mean $(M)$ and error of representativeness $(m)$. We used Mann-Whitney test to determine whether discrepancies between the test and reference groups were significant. Data were statistically processed with Statistica 10 software.

To perform comparative analysis of predicted negative effects among the examined children aged $4-6$, we took data on morbidity among children aged 10-12 (as per ICD-10) obtained via profound medical examinations.

Marker protein stains were substantiated basing on detected authentic cause-and-effect relations described with multi-factor models showing «statistically significant stain - nickel

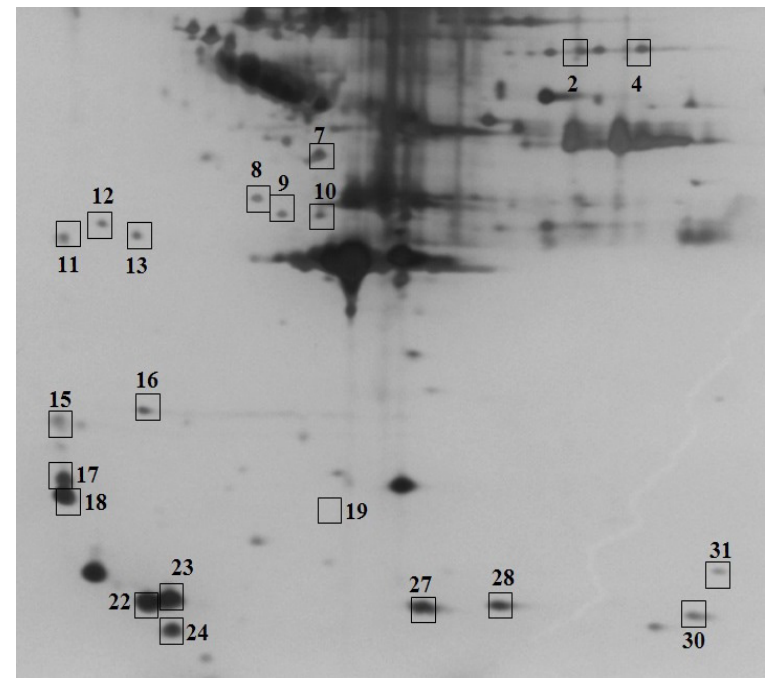

Figure 1. A part of 2DE-gel of children's blood plasma: a child from the test group, number of protein stains are given concentration in blood» dependence with linear regression. To test whether the obtained models were valid and relevant, we performed dispersion analysis with Fischer's test $F$, determination coefficient $\left(R^{2}\right)$, and Student's t-test with statistical significance taken as $p \leq 0.05$.

Results and discussion. We analyzed results obtained via chemical-analytical examination aimed at determining nickel and copper contents in blood; the analysis revealed that children in the test group had 1.2 times higher copper contents in blood $\left(1.04 \pm 0.09 \mathrm{mg} / \mathrm{dm}^{3}\right)$ against the reference group $\quad\left(0.87 \pm 0.09 \mathrm{mg} / \mathrm{dm}^{3}\right) \quad(p=0.011)$; nickel contents in their blood was also up to 3.5 times higher $\left(0.007 \pm 0.002 \mathrm{mg} / \mathrm{dm}^{3}\right)$ against the same parameter $\left(0.002 \pm 0.0001 \mathrm{mg} / \mathrm{dm}^{3}\right)$ in the reference group $(p=0.001)$. A share of samples with nickel and copper contents being higher than reference values ${ }^{4}\left(\mathrm{RfL}_{\text {copper }}=\right.$ $=0.09 \mathrm{mg} / \mathrm{dm}^{3}, \mathrm{RfL}_{\text {nickel }}=0.001 \mathrm{mg} / \mathrm{dm}^{3}$ ) varied from $77.0 \%$ to $82.0 \%$ of all the examined children in the test group whereas it was only from $10.0 \%$ to $20.0 \%$ in the reference group.

Two-dimensional electrophoresis allowed obtaining proteomic blood plasma maps for children from the examined samples; relative protein stains volumes were determined in them via densitometry (Figures 1 and 2).

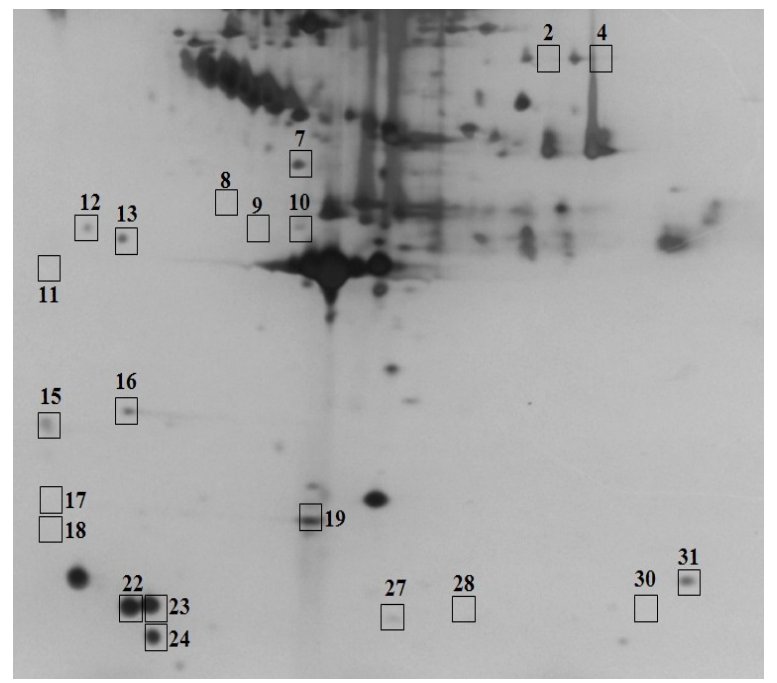

Figure 2. A part of 2DE-gel of children's blood plasma: a child from the reference group, number of protein stains are given

\footnotetext{
${ }^{4}$ N.U. Tits. Clinical guide on laboratory tests. Moscow, UNIMED-press Publ., 2003, 570 p. (in Russian).
} 
We performed comparative analysis of results obtained via densitometry measuring of proteomic blood plasma maps obtained for the examined children; the analysis allowed revealing authentic discrepancies in relative volumes of approximately 20 protein stains between children from the test and the reference group (Table 1).

Children from the test group had proteins stains No. 12 and No. 18 that had 8.0-12.2 times greater volume and protein stain No. 19 that had 5.4 times lower volume than the same stains in children from the reference group $(p=0.0001)$. The above said proteins and genes that code their expression are given in Table 2.

Figure 3 shows an example spectrum for a peptide that has a correlation with simultane- ous elevated copper and nickel contents in blood.

Having built multi-factor models, we established direct cause-and-effect relations between elevated copper and nickel contents in blood and an increase in relative volume of protein stain No. 12 that included a sequence of apolypoprotein A-I and A-kinase 9 anchor protein $\left(R^{2}=0.30 ; b_{0}=-656.8 ; b_{1}=1,801.1\right.$; $\left.b_{2}=63,518.1 ; p=0.008\right)$ and protein stain No. 18 (vitronectin) $\left(R^{2}=0.44 ; b_{0}=-1,372.0\right.$; $\left.b_{1}=2,743.3 ; b_{2}=112,937.0 ; p=0.0001\right)$. We also detected inverse dependence between a decrease in relative volume of protein stain No. 19 that included transthyretin and elevated copper and nickel contents in blood $\left(R^{2}=0.35 ; \quad b_{0}=4,870.1 ; b_{1}=-3,266.9 ; b_{2}=\right.$ $=-79,946.5 ; p=0.003)$.

Table 1

A spectrum showing peptides and proteins determined in proteomic blood plasma profile of children with elevated copper and nickel contents in blood

\begin{tabular}{|c|c|c|c|}
\hline Stain number & Peptide spectrum & $\begin{array}{l}\text { Peptide identifica- } \\
\text { tion probability, } \%\end{array}$ & Protein name \\
\hline \multirow{2}{*}{ Stain No. 2} & RVDGSVDFYRDWATYK & 1.0 & \multirow{2}{*}{ Ficolin-2 } \\
\hline & VDLVDFEDNYQFAK & 56.6 & \\
\hline \multirow{3}{*}{ Stain No. 4} & VDGSVDFYR & 88.0 & \multirow{2}{*}{ Ficolin -2} \\
\hline & VDLVDFEDNYQFAK & 99.0 & \\
\hline & VNVDEVGGEALGR & 99.0 & Hemoglobin subunit beta \\
\hline Stain No. 8 & INGKPLPGATPAK & 40.6 & tRNAselenocysteine 1-associated protein 1 \\
\hline \multirow{7}{*}{ Stain No. 9} & GLCVATPVQLR & 99.0 & \multirow{3}{*}{ Complement component C4-B } \\
\hline & GSFEFPGDVSK & 64.9 & \\
\hline & LGQYASPTAKRCCQDGVTR & 1.0 & \\
\hline & QRIEALSLMHPSISFSLR & 59.0 & \multirow{3}{*}{ DNA mismatch repair protein Mlh3 } \\
\hline & DSEATR & 1.0 & \\
\hline & FYGFR & 1.0 & \\
\hline & GVGKVPR & 34.1 & P2Y purinergic receptor 12 \\
\hline Stain No. 10 & NIVQNVR & 26.1 & Sideroflexin-3 \\
\hline \multirow{4}{*}{ Stain No. 11} & VSFLSALEEYTK & 99.0 & \multirow{3}{*}{ Apolypoprotein A-I } \\
\hline & QGLLPVLESFK & 33.6 & \\
\hline & VKDLATVYVDVLK & 3.8 & \\
\hline & VDTLEIQGDVTLSYVQIR & 32.2 & Galectin-4 \\
\hline \multirow{3}{*}{ Stain No. 12} & DYVSQFEGSALGK & 99.0 & \multirow{2}{*}{ Apolypoprotein A-I } \\
\hline & QGLLPVLESFK & 59.9 & \\
\hline & LLKILLEVVK & 52.3 & A-kinase 9 anchor protein \\
\hline \multirow[t]{8}{*}{ Stain No. 13} & CYTAVVPLVYGGETK & 99.0 & \multirow{4}{*}{ Immunoglobulin J-chin } \\
\hline & FVYHLSDLCK & 99.0 & \\
\hline & AVHVKAQEDER & 1.0 & \\
\hline & NHLLFWGVLAFIK & 1.0 & \\
\hline & RPSTPR & 73.2 & \multirow[t]{4}{*}{ Protein faggot } \\
\hline & EKQFLNAESAYMDPMK & 0.2 & \\
\hline & DRGGRDYPPLR & 1.0 & \\
\hline & DSTSTAPDSQR & 0.1 & \\
\hline
\end{tabular}




\begin{tabular}{|c|c|c|c|}
\hline & LEPLGPGSSGRPGK & 1.0 & \\
\hline & VLRDGGCSLPIIPNITK & 0.2 & \\
\hline & HRAAEAAINILK & 72.9 & $\begin{array}{l}\text { Interferon-induced activator of two-chain } \\
\text { RNA-dependent protein kinase A }\end{array}$ \\
\hline & GLEEELQFSLGSK & 99.0 & Comnlement comnonent $\mathrm{C}_{4}-\mathrm{B}$ \\
\hline Stain No 15 & DVPRGQVVK & 1.0 & 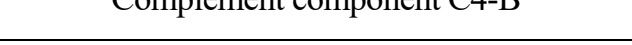 \\
\hline Stain No. 15 & HQDFNSAVQLVENFCR & 99.0 & Prothrombin \\
\hline & LAVTTHGLPCLAWASAQAK & 18.3 & Protnrombin \\
\hline & GLEEELQFSLGSK & 99.0 & Complement component $\mathrm{C} 4-\mathrm{B}$ \\
\hline Stain No. 16 & MPYSVGFR & 23.6 & Ankyrin-1 \\
\hline & CYGMTDDKVDK & 1.0 & Anкугіn-1 \\
\hline Stain No. 17 & SIAQYWLGCPAPGHLR & 77.2 & Vitronectin \\
\hline Stain No. 18 & SIAQYWLGCPAPGHLR & 95.9 & Vitronectin \\
\hline & GSPAINVAVHVFR & 99.0 & \\
\hline Stain No 19 & TSESGELHGLTTEEEFVEGIYK & 99.0 & Transthyretin \\
\hline Stam No. 19 & ALGISPFHEHAEVVFTANDSGPR & 94.7 & Iranstuyreum \\
\hline & AADDTWEPFASCK & 99.0 & \\
\hline & DALSSVQESQVAQQAR & 99.0 & Anolvnonrotein C-III \\
\hline & GWVTDGFSSLK & 99.0 & \\
\hline Stain No. 22 & DLTEAVPR & 94.1 & Myotubularin \\
\hline Stam No. 22 & RDGPGLER & 42.7 & $\begin{array}{c}\text { NAD-dependent protein -diacetyl ASA-sirtuin- } \\
1\end{array}$ \\
\hline & LKSGSGPVR & 32.4 & Necleoplasmin-3 \\
\hline & SIAQYWLGCPAPGHLR & 99.0 & Vitronectin \\
\hline Stain No. 23 & DALSSVQESQVAQQAR & 3.9 & Anolynonrotein C-III \\
\hline & GWVTDGFSSLK & 42.2 & Aporypoprotein C-III \\
\hline Stain No. 24 & ESLSSYWESAK & 99.0 & Apolypoprotein C-II \\
\hline & FFGHGAEDSLADQAANEWGR & 96.5 & Serum amyloid protein $A_{-}$ \\
\hline Stain No. 27 & FFGHGAEDSLAPQAANEWGR & 1.0 & Serum amyiora protem A-1 \\
\hline & RGPGGAWAAEVISNAR & 93.0 & Serum amyloid protein A-2 \\
\hline & SFFSFLGEAFDGAR & 99.0 & Serum amyloid protein A-2 \\
\hline & LVAASQAALGLK & 79.1 & \\
\hline Stain No. 28 & APLAKYIGENQDSISSK & 1.0 & Albumin \\
\hline & YIGENQDSISSKLK & 1.0 & Aloumm \\
\hline & VFDEFKPLVEEPQNLIK & 99.0 & \\
\hline & SAVTALWGK & 99.0 & \\
\hline Stain No. 30 & VNVDEVGGEALGR & 99.0 & Hemoglobin subunit beta \\
\hline & VLGAFSDGLAHLDNLK & 55.6 & \\
\hline Stain No. 31 & LLVVYPWTQR & 99.0 & Hemoglobin subunit gamma-2 \\
\hline
\end{tabular}

Table 2

Proteins and genes coding them that have a correlation with elevated nickel and copper contents in blood

\begin{tabular}{|c|c|c|c|c|c|c|}
\hline \multirow{2}{*}{$\begin{array}{l}\text { Protein } \\
\text { stain } \\
\text { No. }\end{array}$} & \multirow{2}{*}{$\begin{array}{l}\text { A trend in } \\
\text { protein vol- } \\
\text { ume change }\end{array}$} & \multirow{2}{*}{ Protein } & \multicolumn{2}{|c|}{$\begin{array}{l}\text { Relative volume of protein stain } \\
(\mathrm{M} \pm \mathrm{m}), \text { int }^{*}\end{array}$} & \multirow{2}{*}{$\begin{array}{l}\text { A gene } \\
\text { that codes } \\
\text { a protein }\end{array}$} & \multirow{2}{*}{$\begin{array}{c}\text { Code of a gene } \\
\text { that codes a pro- } \\
\text { tein in Sviss } \\
\text { Prot database }\end{array}$} \\
\hline & & & $\begin{array}{l}\text { Test group } \\
(n=20)\end{array}$ & $\begin{array}{c}\text { Reference group } \\
(n=10)\end{array}$ & & \\
\hline \multirow{2}{*}{12} & \multirow{2}{*}{ Increase } & Apolypoprotein A-I & \multirow{2}{*}{$2,099 \pm 135^{* *}$} & \multirow{2}{*}{$171 \pm 46$} & APOA1 & P02647 \\
\hline & & A-kinase 9 anchor protein & & & AKAP9 & Q99996 \\
\hline 18 & Increase & Vitronectin & $2,731 \pm 337^{* *}$ & $340 \pm 101$ & VTN & P04004 \\
\hline 19 & Decrease & Transthyretin & $498 \pm 143^{* *}$ & $2,687 \pm 746$ & TTR & P02766 \\
\hline
\end{tabular}

Note:

int $_{* *}^{*}$ means protein stain intensity;

${ }^{* *}$ means discrepancies between mean values are valid, $p \leq 0.05$. 


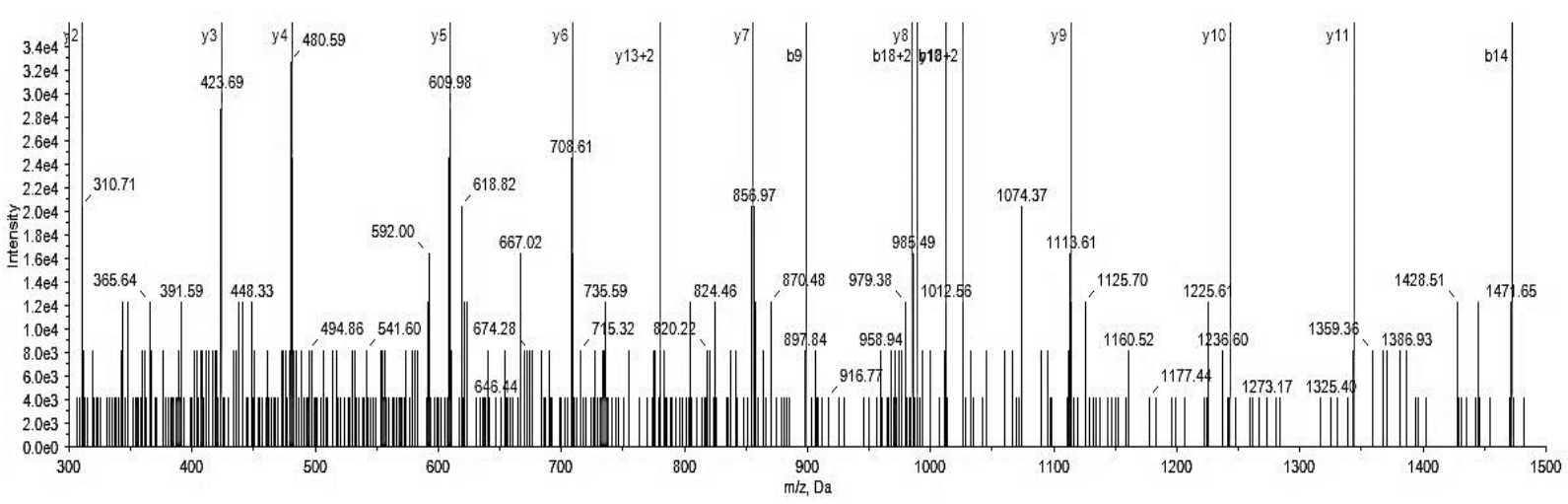

Figure 3. Spectrum for TSESGELHGLTTEEEFVEGIYK peptide (Transthyretin)

(SwissProt database) in a child's blood plasma, stain No. 19

We analyzed biological functions performed by the identified proteins in blood plasma as per data provided in both Russian and foreign scientific works; the results allow predicting certain adverse effects occurring in the cardiovascular and nervous system. Thus, indentified apolypoprotein A-I and vitronectin are predominantly connected with endothelial dysfunction that in future may result in arterial hypertension and cardiomyopathy [10]. Apolypoprotein A-I belongs to high density lipoproteins; it releases cells from excessive cholesterol thus preventing atherosclerosis plaques formation and making for greater elasticity of vessels endothelium [11-13]. Vitronectin is a cellular-adhesive glycoprotein produced and released by liver cells; in pathologic state it is bonded with cellular surfaces, for example, with activated thrombocytes and extracellular matrices in various tissues (fibrin) [14]. As a result, thrombocytes adhesion and their local aggregation enhance as it has been confirmed via experimental research $[15$, $16]$. In case there is a growth in relative volume of a protein stain that contains apolypoprotein A-I and vitronectin and nickel and copper contents in blood are elevated, we can predict damage to endothelial cells of blood vessels done by reactive oxygen species, anti-inflammation reaction being induced, and cytokines being released from heart tissues via such transcription factors as $\mathrm{NF}-\kappa \mathrm{B}$ (nuclear factor kappa-B) and AP-1 (activator protein 1) as it was described in several foreign and Russian research works $[17,18]$.

A-kinase 9 anchor protein characterizes changes in neural regulation since several its isoforms are able to get bonded to N-methyl$\mathrm{D}$-aspartate receptor in neuromuscular junction and neuron synapses; it means that there are changes in how postsynaptic specialization is organized [19]. As per data obtained via experimental research, excessive expression of this protein may result in mitochondria becoming longer and an in increase in membrane potential thus making neurons less sensitive to constant strain in transferring signals $[19,20]$. Transthyretin, in its turn, is a protein that plays an important role in the nervous system development, neuronal growth and synapses genesis as well as cytoarchitecture regulation that support cognitive functions performed by the central nervous system (memory, emotional state, and mental health) $[21,22]$. This assumption is confirmed by results obtained via experimental research performed by foreign experts [21, 23]. Changes in transthyretin expression may lead to various cognitive disorders and behavioral deviations [23].

We performed comparative analysis of established changes in proteomic blood plasma profile of children aged 4-6 and negative effects that turned into actual diseases in children aged 10-12; the results allowed revealing authentic 2.2-3.0 times greater frequency of cardiovascular diseases (cardiomyopathy, I42) 
and diseases of the nervous system (functional disorders of the central and vegetative nervous system, G90.9, G90.8) against the same parameters in the reference group $(p=0.001-0.032)$. And we also established authentic dependence between greater frequency of nervous diseases (functional disorders in the nervous system) and cardiomyopathy and elevated copper and nickel contents in blood for children aged $10-12 \quad\left(R^{2}=0.35-0.96 ; \quad-1.94 \leq b_{0} \geq-7.22\right.$; $\left.1.76 \leq b_{1} \geq 128.64 ; p=0.0001-0.013\right)$.

Therefore, the described and grounded omic-markers (apolypoprotein A-I, vitronectin, A-kinase 9 anchor protein, and transthyretin) and genes that code their expression (APOA1, VTN, AKAP9, and TTR) can be used to achieve more efficient prediction of negative effects related to disorders in neural regulation and endothelial dysfunction; it will allow early detection and prevention of negative outcomes for children's health under high aerogenic exposure to copper and nickel.

\section{Conclusions.}

1. Approximately 20 protein stains were authentically different in children from the test group with copper and nickel contents in blood being up to 3.5 times higher than in the reference group.

2. We established dependences between elevated copper and nickel contents in blood and an increase in relative volume of three protein stains that contained apolypoprotein
A-I, A-kinase 9 anchor protein, and vitronectin, and a decrease in relative volume of one protein stain that contained transthyretin $\left(R^{2}=0.30-0.44 ; p=0.0001-0.008\right)$.

3 . Changes in relative volume of protein stains that include apolypoprotein A-I, A-kinase 9 anchor protein, vitronectin, and transthyretin have predictive significance for determining probable negative effects related to neural regulation disorders and endothelial dysfunction.

4. Predicted negative effects were proven to actually occur as elevated frequency of nervous and cardiovascular diseases in case copper and nickel concentrations in blood were elevated $\left(R^{2}=0.35-0.96 ; p=0.0001-0.013\right)$.

5 . To predict probable negative effects occurring in the cardiovascular and nervous system prior to actual damage done to tissues and organs, we substantiated use of omicmarkers given ass proteins (apolypoprotein A-I, vitronectin, A-kinase 9 anchor protein, and transthyretin) and genes that code their expression (APOA1, VTN, AKAP9, TTR); these markers allow identifying transformed proteomic profiled associated with aerogenic exposure to copper and nickel.

Funding. The research was not granted any sponsor support.

Conflict of interests. The authors declare there is no any conflict of interests.

\section{References}

1. Barbarini N., Magni P. Accurate peak list extraction from proteomic mass spectra for identification and profiling studies. BMC. Bioinformatics, 2010, vol. 11, no. 518, pp. 1-14. DOI: 10.1186/1471-2105-11-518

2. Shenderov B.A. «Omik»-tekhnologii i ikh znachenie v sovremennoi profilakticheskoi i vosstanovitel'noi meditsine [«Omic»-technologies and their significance for contemporary preventive and recovery medicine]. Vestnik vosstanovitel'noi meditsiny, 2012, no. 3, pp. 70-78 (in Russian).

3. Polunina T.A., Varshavskaya Yu.S., Grigor'eva G.V., Krasnov Ya.M. Proteomic methods of protein separation and analysis. Zhurnal mikrobiologii, epidemiologii i immunobiologii, 2014, no. 3, pp. 107-114 (in Russian).

4. Ahn S.-M., Simpson R.J. Body fluid proteomics: Prospects for biomarker discovery. Proteomics Clin. Appl., 2007, vol. 1, no. 9, pp. 1004-1015. DOI: 10.1002/prca.200700217

5. Larina I.M., Ivanisenko V.A., Nikolaev E.N., Grigorev A.I. The proteome of a healthy human during physical activity under extreme conditions (Reviews). Acta Naturae, 2014, vol. 6, no. 3 (22), pp. 66-75. 
6. Aebersold R., Agar J., Amster I., Baker M.S., Bertozzi C.R., Boja E.S., C.E. Costello, B.F. Cravatt [et al.]. How many human proteoforms are there? Nature chemical biology, 2018, vol. 14, no. 3, pp. 206-214. DOI: 10.1038/nchembio.2576

7. PROTEAN i12 IEF System. Instruction Manual. Hercules, Bio-Rad Laboratories, Inc Publ., 2011,60 p.

8. PROTEAN II xi 2D cell. Instruction Manual. Hercules, Bio-Rad Laboratories, Inc Publ., $2011,52 \mathrm{p}$.

9. ReadyPrep 2-D starter Kit. Instruction manual. Hercules, Bio-Rad Laboratories, Inc Publ., 2011, 28 p.

10. Wu S., Deng F., Wei H., Huang J., Wang H., Shima M., Wang X., Qin Y. [et al.]. Chemical constituents of ambient particulate air pollution and biomarkers of in flammation, coagulation and homocysteine in healthy adults: a prospective panel study. Part. Fibre. Toxicol., 2012, vol. 9, no. 49, pp. 1-13. DOI: 10.1186/1743-8977-9-49

11. Knyazev R.A., Trifonova N.V., Ryabchenko A.V., Kotova M.V., Kolpakov A.R., Polyakov L.M. Impact of recombinant apolipoprotein A-I on myocardial function in experiment. Patologiya krovoobrashcheniya i kardiokhirurgiya, 2018, vol. 22, no. 4, pp. 88-94 (in Russian).

12. Maranhão R.C., Freitas F.R. HDL Metabolism and Atheroprotection: Predictive Value of Lipid Transfers. Advances in Clinical Chemistry, 2014, no. 65, pp. 1-41. DOI: 10.1016/B978-0-12800141-7.00001-2

13. Chumakova G.A., Gritsenko O.V., Veselovskaya N.G., Vakhromeeva E.V., Kozarenko A.A. Clinical role of apolipoproteins A and B. Kardiovaskulyarnaya terapiya i profilaktika, 2011, vol. 10, no. 6, pp. 105-111 (in Russian).

14. Masaharu H., Takeshi Y., Katsuko N., Ai S.-N., Tomoko F., Yuichi M., Takaya G., Katsushi T. Vitronectin improves cell survival after radiation injury in human umbilical vein endothelial cells. FEBS Open Bio, 2012, no. 2, pp. 334-338. DOI: 10.1016/j.fob.2012.10.002

15. Ruggeri Z.M., Jackson S.P. Platelet Thrombus Formation in Flowing Blood. Platelet biology, 2013, no. 2, pp. 399-423. DOI: 10.1016/B978-0-12-387837-3.00020-1

16. Konstantinides S., Schafer K., Thinnes T., Loskutoff D.J. Plasminogen activator inhibitor-1 and its cofactor vitronectin stabilize arterial thrombi after vascular injury in mice. Circulation, 2001, no. 103 , pp. 576-583. DOI: 10.1161/01.cir.103.4.576

17. Sarnat S.E., Winquist A., Schauer J.J., Turner J.R., Sarnat J.A. Fine particulate matter components and emergency department visits for cardiovascular and respiratory diseases in the St. Louis, Missouri-Illinois, Metropolitan Area. Environ. Health Perspect, 2015, vol. 5, no. 123, pp. 437-444. DOI: 10.1289/ehp.1307776

18. Kolpakova A.F., Sharipov R.N., Kolpakov F.A. Air pollution by particulate matter as the risk factor for the cardiovascular diseases. Gigiena i sanitariya, 2017, vol. 96, no. 2, pp. 133-137 (in Russian).

19. Liu Yu., Merrill R.A., Strack S. A-Kinase Anchoring Protein 1: Emerging Roles in Regulating Mitochondrial Form and Function in Health and Disease (Review). Cells, 2020, vol. 9, no. 298, pp. 2-12. DOI: $10.3390 /$ cells 9020298

20. Flippo K.H., Gnanasekaran A., Perkins G.A., Ajmal A., Merrill R.A., Dickey A.S., Taylor S.S., McKnight G.S. [et al.]. AKAP1 Protects from Cerebral Ischemic Stroke by Inhibiting Drp1Dependent Mitochondrial Fission. J. Neurosci, 2018, vol. 19, no. 38, pp. 8233-8242. DOI: 10.1523/JNEUROSCI.0649-18.2018

21. Remaud S., Gothié J.-D., Morvan-Dubois G., Demeneix B.A. Thyroid hormone signaling and adult neurogenesis in mammals. Front. Endocrinol, 2014, vol. 5, no. 62, pp. 1-7. DOI: $10.3389 /$ fendo.2014.00062

22. V'yunova T.V., Medvedeva E.V., Andreeva L.A., Dergunova L.V., Limborskaya S.A., Myasoedov N.F. A possible role of transthyretin in the biological mechanism of regulatory peptide neuroprotection. Molekulyarnaya genetika, mikrobiologiya i virusologiya, 2016, vol. 34, no. 3, pp. 104-109 (in Russian). 
23. Brouillette J., Quirion R. Transthyretin: a key gene involved in the maintenance of memory capacities during aging. Neurobiol. Aging., 2008, vol. 29, no. 11, pp. 1721-1732. DOI: 10.1016/j.neurobiolaging.2007.04.007

Zaitseva N.V., Zemlyanova M.A., Koldibekova Yu.V., Bulatova N.I. Omic markers identification for predicting risks of negative effects in children with elevated copper and nickel contents in blood. Health Risk Analysis, 2021, no. 1, pp. 48-56. DOI: 10.21668/health.risk/2021.1.05.eng

Received: 12.01 .2021

Accepted: 15.03 .2021

Published: 30.03 .2021 